\title{
Performance of a Large-Scale Medical Waste Incinerator in a Referral Hospital
}

\author{
Veilla E. Matee, Samwel V. Manyele \\ Department of Chemical and Mining Engineering, University of Dar es Salaam, Dar es Salaam, Tanzania \\ Email: veilla.elisante@mnh.or.tz, smanyele@udsm.ac.tz
}

Received 29 May 2015; accepted 27 October 2015; published 30 October 2015

Copyright (C) 2015 by authors and Scientific Research Publishing Inc.

This work is licensed under the Creative Commons Attribution International License (CC BY). http://creativecommons.org/licenses/by/4.0/

(c) (i) Open Access

\section{Abstract}

The aim of the study was to analyze the performance of large scale incinerator installed in a referral hospital. The study involved weighing and loading infectious waste of different composition (sharps and other waste), recording temperatures in the primary and secondary chamber with time, fuel used and collecting and weighing the bottom ash for 65 days. The analysis shows that the incinerator on average uses $362 \mathrm{~L} / \mathrm{day}(45 \mathrm{~L} / \mathrm{h})$ to incinerate $945 \mathrm{~kg}$ of medical waste $(40.8$ $\mathrm{kg} /$ day of sharps waste and $904 \mathrm{~kg} /$ day of other waste), generating $51.2 \mathrm{~kg}$ of ash daily. The observed fuel consumption rate was too high necessitating corrective action. The average weight reduction was $\mathbf{9 4 . 6 \%}$. The study shows that the average sharps waste composition for medical waste incinerated was $4.3 \%$ and other waste was $95.7 \%$. The incinerator capacity ranged between 100 and $130 \mathrm{~kg} / \mathrm{h}$. The fuel effectiveness ranged between 2.0 and 3.0 liters of diesel per $\mathrm{kg}$ of waste incinerated. The fuel effectiveness increased linearly with total waste incinerated and incinerator capacity, respectively, depending on the fuel consumption rate.

\section{Keywords}

Medical Waste Incinerator, Large-Scale Incinerator, Sharps Waste, Fuel Consumption, Fuel Effectiveness, Incinerator Capacity, Incinerator Ash

\section{Introduction}

Muhimbili National Hospital (MNH) is a National Referral Hospital and University Teaching Hospital with 1500 bed facility, attending up to 1200 outpatients per day, while admitting an equal number of inpatients per day. The generation, segregation, collection, transport and disposal of medical waste must be properly managed 
so as to minimize the risks to health care provider, patients, the public and safety of the surrounding environment [1]. Improper disposal of medical waste including ash sent to the landfill may increase the risk of spreading infections and of exposure to toxic chemicals [2] [3]. Literature shows, however, that incinerator ash gives assistance to the biodegradation of organic waste in the landfills [4] [5]. This study focuses on medical waste treatment and final disposal.

Sharps waste generated at MNH range between 30 - $50 \mathrm{~kg}$ and other infectious wastes generated is between 800 - $1000 \mathrm{~kg}$ per day [6]. The problem of sharps overfilling and mixing of infectious waste with non infectious waste is commonly observed at $\mathrm{MNH}$, proper management of which is being strongly implemented. Workers in waste disposal facility, including scavengers, the public and more specifically the children are also at risk of the highly infectious sharps waste if proper management is not adhered to [7].

The costs of installing and operating an incinerator include both capital and annual costs. Capital costs are all of the initial equipment-related costs of the incinerator. Annual costs are the direct costs of operating and maintaining the incinerator for one year, plus such indirect costs. Direct annual costs include labor (operating, supervisory, coordinating, and maintenance); maintenance materials; operating materials; electricity; and supplemental fuel. This study was aimed at identifying operational cost constraints posed by fuel consumption so as to advise the MNH management on the way forward. The supplemental fuel requirements for an incinerator are likely to have a large impact on incinerator annual costs. The results of this study had implications on the decision making toward improving the performance and minimizing costs of the incinerator operation.

Despite of large-scale incinerator (with air pollution control device, temperature control and flame ignition burners), the problem of air pollution caused by frequent malfunctioning incinerator was alarming [8]-[10]. Poorly designed and ill-operated medical waste incinerators can be one of the largest sources of dioxin, furan and mercury pollution to the environment. Incineration flue gases can be minimized through use of scrubbers and bughouses when used as air pollution control devices.

MNH uses a large-scale incinerator installed with air pollution control devices, temperature control, flame ignition transformer and burners, performance of which was studied in details [11]-[17]. The incinerator uses semi-automatic waste loading system which lifts the waste, opens the primary chamber loading door at the top and loads by dropping the waste to the bottom of the chamber. The lifting equipment has a capacity of $120 \mathrm{~kg}$ with maximum load bin of $75 \mathrm{~kg}$. Despite the chimney being at a recommended height, the machine produces pollution and choking smell due to type of wastes incinerated, e.g., plastic material, water drinking bottles, catheter, infusion sets (contaminated with blood), waste bags and sharps waste.

The auxiliary fuel for the incinerator studied was diesel oil, consumption of which forms a critical incinerator performance factor. The main advantages of incineration process compared to autoclaving, microwaving or landfill, is volume and weight reduction with proved pathogens elimination. Diesel oil used for incineration is topped up in the reserve tank with capacity of 540 litres. The burners are completely automatic and do not require manual supervision by the operator. The incinerator is designed to operate for 8 hours/day only.

The aim of the study was to analyze the performance of large scale incinerator installed in a referral hospital $(\mathrm{MNH})$. Specifically, the following were performed: studying the design features of the incinerator, weighing and charging infectious wastes of different composition (in terms of varying fraction of sharps and other waste), recording temperatures in the primary and secondary chamber with time, followed by data analysis. The main assumption in this work is that all infectious rate generated is incinerated, thus, waste generation rate equals to the incineration capacity.

\section{Literature Review}

\subsection{Medical Waste Management}

Medical waste management is a core issue in hospitals worldwide [3] [7] [18]-[24]. This is due to the fact that medical waste generated requires attention as may pose disease if not properly handled. Infectious waste is associated with health risks and has become even more significant as the HIV epidemic has been growing, and also due to the prevalence of Hepatitis B and C which has increased significantly [3] [7]. Each injury, where contamination with patient's blood occurs, can be a source of acute or chronic diseases [7]. Medical waste management system is a procedure of managing waste from a point of generation, segregation, collection, transportation, storage and treatment and final disposal. MNH being a referral hospital handles tons of medical waste per year. The WHO suggests that hospital wastes should provide plastic bags and strong plastic containers for infec- 
tious waste.

The categories of medical waste generated in Tanzanian district hospitals included: general waste, pathological waste, radioactive waste, chemical waste, infectious waste, sharps waste, pharmaceutical waste and pressurized containers [24]. The same categories are generated in referral hospitals at varying quantities. Medical waste segregation is an important step in reducing the volume of hazardous waste as it offers the ability to make more accurate assessment about its composition with the use of labelled bags to separate infectious waste from domestic waste effectively [7] [18] [19] [23] [24]. The result from investigation reveals that MNH gave high priority to segregation at the source of infectious and sharps waste by use of colour coding system. All waste generated in the wards is kept in plastic bags which are loaded into 70-litre bins. The waste bins re separated using colour coded, green bin for non-infectious waste and red bin for infectious waste and yellow safety boxes for disposable syringe and other broken glass to allow identification by incinerator operators.

\subsection{Treatment of Medical Waste}

At MNH segregated infectious waste (sharps and other waste) from different sources is collected and transported to the incinerator, in accordance to the national guidelines [25]. The incineration process reduces volume and weight of incinerated waste and hence minimizes infections to health care providers as well as waste handlers. Together with pathogens destruction, incineration of medical waste converts the waste into essentially noncombustible solid residue or ash which can be toxic, thus requiring proper handling [2] [25]-[27]. Large-scale medical waste incinerator is used to treat and decontaminate medical wastes at high temperatures $\left(800^{\circ} \mathrm{C}\right.$ to $950^{\circ} \mathrm{C}$ ) using dry oxidation process that reduces organic and combustible waste to inorganic, incombustible ash [2] [8] [9] [11] [26] [27]. This process reduces weight and volume of the medical waste. The incineration process detoxifies medical waste by destroying most of the microorganisms and organic compounds and reduces the volume and weight of waste leading to inert residual of solids, with an appreciable amount of fuel being consumed [12] [13].

Incineration is a process in which waste is burned under controlled condition to oxidize the organic carbon and hydrogen present in the waste. It is known to be the best available option for treating medical waste particularly the pathological wastes. At MNH, the sharps and other waste are treated together by using a large scale incinerator. Safe disposal of healthcare waste improves working conditions in the hospital, reduces pollution, reduces accidental injuries, increases public safety and reduces the chance of transmission of infectious disease [3] [7].

The first chamber performs pyrolytic destruction of the waste and final combustion of gases takes place in the secondary chamber [11]. During primary combustion process, products of combustion are given off as combustible gases such as carbon monoxide, which enters the secondary combustion chamber for secondary combustion. This raises the temperature in the secondary chamber even higher, reducing the gases to stable compounds such as carbon dioxide.

The fraction of the weight which is volatile matter is changed into gaseous components in the primary chamber, and transformed into water vapor and carbon dioxide in the secondary chamber. Thus, the gaseous flow through the chimney is a huge flow stream which carries part of the waste referred to in this study as weight reduction (about $80 \%$ - 98\% of the total weight of the waste charged [11] [13] [14]. This fraction necessitates use of efficient secondary chamber and air pollution control devices to make sure toxic components are destroyed and captured before entering the atmosphere, since it contains varying amounts of stack gas concentrations, i.e., $\mathrm{SO}_{x}, \mathrm{NO}_{x}, \mathrm{CO}, \mathrm{CO}_{2}$ and $\mathrm{HCl}$ [8] [11] [14]. Incineration with excess supply of oxygen leads to volume reduction and weight reduction. Literature shows volume reduction of up to 1/65 for radioactive combustible waste [14]. While other studies focus on volume reduction, this paper quantifies the weight reduction by weighing the total medical waste loaded and ash collected.

The combustion chamber of an incinerator combines the primary air, fuel, and medical waste [8]-[10] [13] [14]. The fuel is introduced through a burner nozzle and is designed to produce a flame front over the full range of operating conditions. Typically, natural gas, fuel or diesel oil is continuously fed to the combustion chamber where total material and pollutant destruction takes place [12]. The MWI requires a continuous augmented fuel supply to maintain complete combustion and destruction of the primary fuel, that is, medical waste feed [10] [12]-[14]. The use of fuel plays a significant cost component in the incinerator operation, which, can be minimized by optimizing burner efficiency and segregation at the source [23] [24]. 


\section{Materials and Methods}

\subsection{Design Features of the Assessed Incinerator}

Standard fire bricks of approximately $230 \mathrm{~mm} \times 115 \mathrm{~mm} \times 75 \mathrm{~mm}$ and capable of withstanding temperatures of at least $1300^{\circ} \mathrm{C}$ have been used to construct the refractive walls of the primary and secondary chambers [10], each designed to operate using oil burners. An opening on top of the primary chamber allows for automatic waste feeding using a special bin, while a chimney connected at the top of secondary chamber allows for smoke outlet, as shown in Figure 1. The automatic feeding bin is incorporated within the machine. The incinerator is used to destroy all medical waste (sharps and other waste).

The waste is loaded into the primary chamber (where pyrolytic combustion takes place) and final combustion of gases takes place in the secondary chamber. The incinerator uses a manual flue gas temperature control, such that when the temperature of secondary chamber goes higher than the set value $850^{\circ} \mathrm{C}$ the operator has to switch on the small water pump which produces spray of water to cool down the flue gases. Both burners are incorporated with temperature controller which displays the combustion temperatures on each cycle. The maximum temperature was about $900^{\circ} \mathrm{C}$ in secondary chamber and about $850^{\circ} \mathrm{C}$ in the primary chamber. The incinerator was operated to burn about $70 \mathrm{~kg}$ of medical waste per cycle comprising of varying proportions of sharps and other waste).

\subsection{Data Collection}

The data included temperatures, weight of sharps waste and other waste incinerated, and the daily fuel consumption. Based on data on sharps and other waste loaded, the total waste incinerated was determined. The data was recorded for 65 days. Table 1 shows the sample data collection worksheet. The waste composition was determined from the sharps and other waste data.

Data was entered into the computer using a data base created in MS Excel. The data was then transferred directly into SPSS DATA editor. The data was processed by invoking the descriptive statistic and focusing on frequencies. The output from the software contained graphical presentations (histograms and pie charts) as well as tabulated statistical information (mean, standard deviation, skewness and kurtosis). The input parameter studied include: sharps waste loaded, other waste loaded, total diesel oil consumed per day by the two burners, and incineration cycle time. The mathematical derivations for the parameters studied (total weight of loaded, mass fractions of sharps waste and other waste, incinerator capacity and fuel effectiveness), have been published using data from a district hospital incinerator [12] [15] [17].

The percentage weight reduction was determined in this study by measuring the weight of medical waste before incineration and followed by collecting and weighing the ashes before final disposal [2] [12] [14] [26]. However, chemical composition and physical properties of ashes were not tested [2] [4] [26] [27].

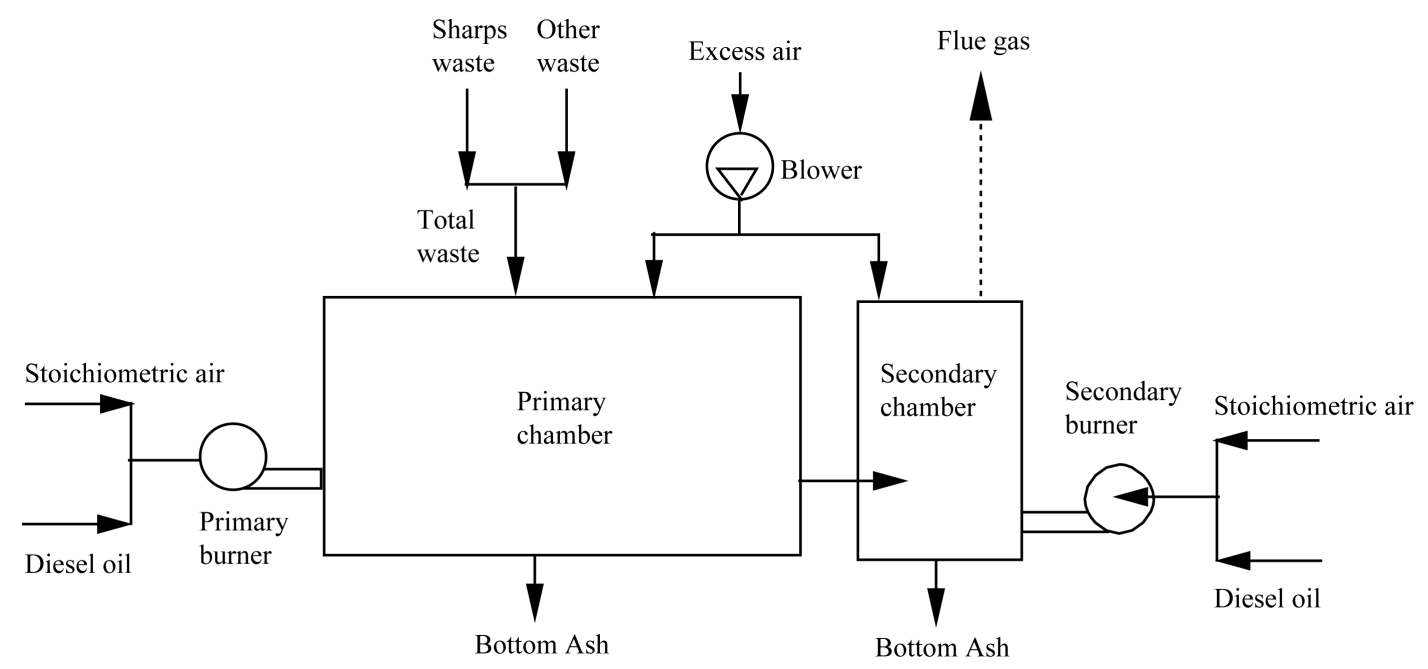

Figure 1. Design features of the assessed incinerator. 


\section{Results and Discussion}

\subsection{Distribution of Daily Medical Waste Incineration Data}

Based on statistical data analysis for waste incinerated it was revealed that the sharps waste ranged between 15 and $86 \mathrm{~kg} /$ day with mean value of $40.8 \mathrm{~kg} /$ day and standard deviation of 17.1, while other waste ranged between 800 and $934 \mathrm{~kg} /$ day with mean value of $904.1 \mathrm{~kg} /$ day. The detailed statistical analysis of the daily incineration data are shown in Table 2. Using absolute values of standard deviation, it can be seen that there were stronger fluctuations in other waste data than in sharps waste data (high standard deviation) similar to observations reported in district hospitals [16] [24]. However, when the ratio of standard deviation is used, $\sigma / \overline{\mathrm{X}}$, it is clear that the fluctuations are stronger in sharps waste (41.91\%) than in the other waste (2.76\%). The ash weight data also shows stronger fluctuations at $27.73 \%$, indicating poor segregation of the waste at the source. Table 2 shows the comparison of the fluctuations in the daily incineration data collection using the signal to noise ratio, whereby, large values of the ratio indicates stronger fluctuations in the data.

The total waste incinerated ranged between 823 and $1018 \mathrm{~kg} /$ day with an average of $945 \mathrm{~kg} / \mathrm{day}$ or $118.1 \mathrm{~kg} / \mathrm{h}$ for daily operation of 8 hours. During this period of study, 58.8 and 2.7 tons of other waste and sharps waste were incinerated, equivalent to 61.4 tons of the total infectious waste while consuming 23,535 liters of diesel oil. Given that, a total of 3.3 tons of ash was collected, then 58.1 tons of the volatile matter was released into the

Table 1. Sample data collection worksheet.

\begin{tabular}{cccccc}
\hline \multirow{2}{*}{ Date } & Other waste loaded & Sharps waste loaded & Ash collected & Total operating time & \multicolumn{2}{c}{ Diesel oil used } \\
\cline { 2 - 6 } & $\mathrm{O}_{\mathrm{w}}(\mathrm{kg})$ & $\mathrm{S}_{\mathrm{w}}(\mathrm{kg})$ & $\mathrm{W}_{\text {as }}(\mathrm{kg})$ & $\mathrm{T}_{\mathrm{op}}(\mathrm{hrs})$ & $\mathrm{D}_{\mathrm{o}}(\mathrm{L})$ \\
\hline Day 1 & 921 & 42 & 70 & 8 & 365 \\
Day 2 & 929 & 56 & 78 & 8 & 360 \\
Day 3 & 932 & 85 & 87 & 8 & 365 \\
Day 4 & 922 & 75 & 78 & 8 & 360 \\
Day 5 & 932 & 46 & 84 & 8 & 365 \\
Day 6 & 920 & 39 & 70 & 8 & 360 \\
Day 7 & 927 & 35 & 76 & 8 & 365 \\
$\ldots$ & $\ldots$ & $\ldots$ & $\ldots$ & 8 & $\ldots$ \\
Day 65 & 800 & 23 & 42 & & 360 \\
\hline
\end{tabular}

Table 2. Statistical analysis of the daily medical waste incinerated data.

\begin{tabular}{|c|c|c|c|c|c|}
\hline & Other waste (kg) & Sharps waste (kg) & Total waste (kg) & Weight of ash (kg) & Diesel oil used (L) \\
\hline $\mathrm{N}$ & 65 & 65 & 65 & 65 & 65 \\
\hline Mean & 904.1 & 40.8 & 944.9 & 51.2 & 362.1 \\
\hline Std. Deviation & 25.0 & 17.1 & 32.1 & 14.2 & 2.9 \\
\hline$\sigma / \overline{\mathrm{X}}, \%$ & $2.76 \%$ & $41.91 \%$ & $3.40 \%$ & $27.73 \%$ & $0.80 \%$ \\
\hline Signal-to-noise ratio & 36.16 & 2.38 & 29.44 & 3.61 & 124.86 \\
\hline Skewness & -3.09 & 1.03 & -0.53 & 0.61 & 0.10 \\
\hline Kurtosis & 11.34 & 0.57 & 3.49 & 0.72 & -0.40 \\
\hline Minimum & 800 & 15 & 823 & 20 & 355 \\
\hline Maximum & 934 & 86 & 1018 & 87 & 370 \\
\hline Sum & 58,765 & 2651 & 61,416 & 3328 & 23,535 \\
\hline
\end{tabular}


atmosphere, neglecting volatiles from auxiliary fuel.

Figure 2 shows the probability density functions of other waste and sharps waste incineration data. The two plots are different in nature showing that the data originate from two systems controlled by different factors. While other waste data is highly skewed $(\mathrm{Sk}=-3.09)$ to the left (where small quantities of waste occur at lower frequencies), the sharps waste data is slightly closer to the normal distribution (slightly skewed to the right (Sk = 1.03) where large amounts of sharps waste occur at lower frequencies, due to emergencies referred to $\mathrm{MNH}$ from hospitals in the city of Dar es Salaam. However, most of the other waste data was closer to the mean $(\mathrm{Ku}=$ 11.34) compared to the sharps waste data which is widely spread on both sides of the mean $(\mathrm{Ku}=0.57)$. Such variations in medical waste generation and collection has been also reported $n$ other hospitals [11] [16] [17] [24] [28]. The fluctuations in sharps waste can be attributed to frequent emergency cases in the referral hospital which calls for preferential use of injection treatment option instead of oral medication.

Figure 3 shows the PDF of the total medical waste incineration data for 65 days. The average total medical waste incinerated at $\mathrm{MNH}$ was observed to be $945 \mathrm{~kg} /$ day which is equivalent to $0.5 \mathrm{~kg} / \mathrm{patient} / \mathrm{day}$ (or 0.947 $\mathrm{kg} / \mathrm{bed} / \mathrm{day}$ ). The data is normally distributed with low positive skewness, $\mathrm{Sk}=0.204$. The fluctuations in total waste incinerated data shows a low negative skewness ( $\mathrm{Sk}=-0.53$ ), such that few values with rather low qunatities of waste incinerated were observed at low frequencies attributed to poor segregation and collection efficiency in the waste generation sites. The mean value for the total medical waste incinerated was observed to be $945 \mathrm{~kg} /$ day, which indicate that on average, $118 \mathrm{~kg}$ are incinerated per hour. The negative skewness value can be attributed to poor waste collection efficiency leading to lower values of total waste incinerated in some cases.

\subsection{Composition of Waste Incinerated}

The characteristic of waste to be incinerated affects the cycle time and temperature profile in various section of incinerator during a burning cycle. The variation will also influence the duration of primary burner operation, especially when the waste is wet. In this study the waste composition was based on two categories of waste: sharps waste and other waste. Table 3 shows the waste composition in terms of sharps and other waste. The composition was expressed as $\mathrm{X}$ ( $\mathrm{kg}$ other waste per $\mathrm{kg}$ total waste) and $\mathrm{Y}$ ( $\mathrm{kg}$ of sharps waste per $\mathrm{kg}$ total waste).

Figure 4 present the PDFs of $\mathrm{X}$ and $\mathrm{Y}$ values observed in this study. It should be noted that $\mathrm{X}$ and $\mathrm{Y}$ are random variables governed by the fluctuations in the quantities of the incoming waste to incinerator facility. The sharps waste composition varied between $1 \%$ to $9 \%$, while the other waste varied between $91 \%$ to $99 \%$ with mean values of $4 \%$ and $96 \%$ respectively.
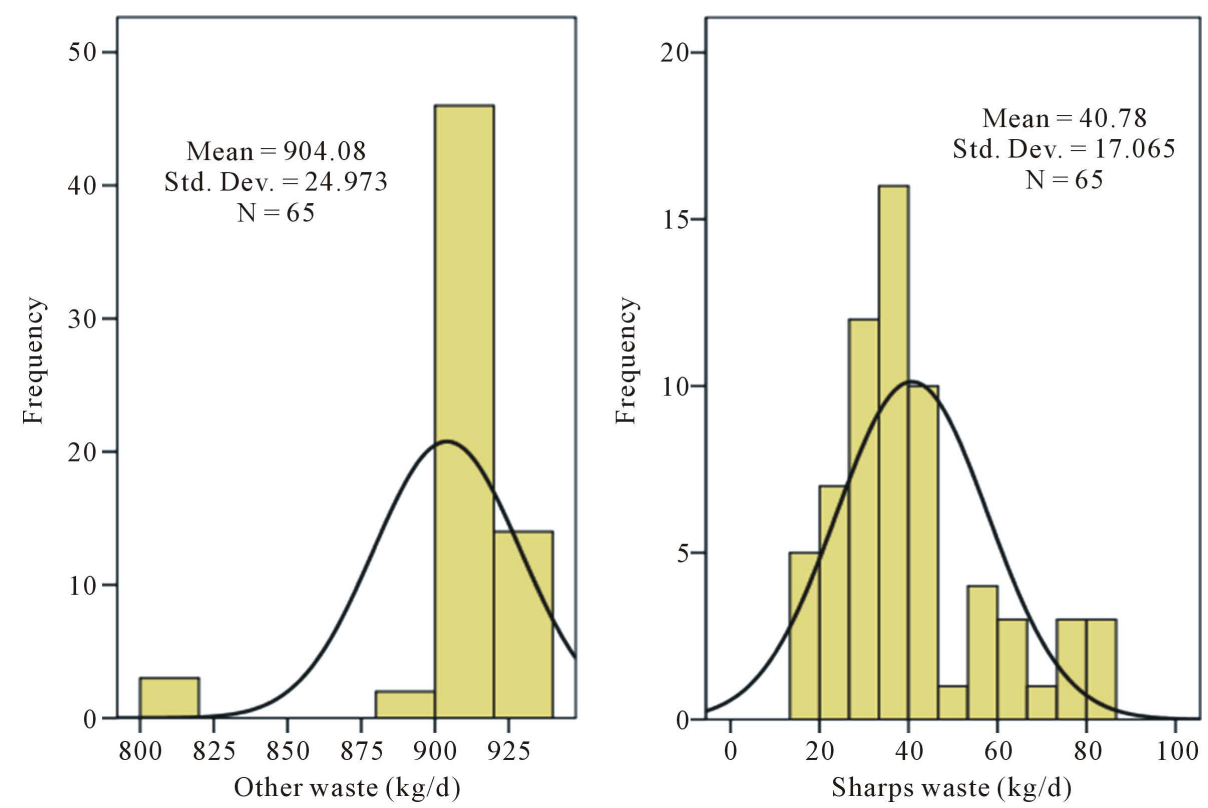

Figure 2. Distribution of the daily other waste and sharps waste data incinerated. 


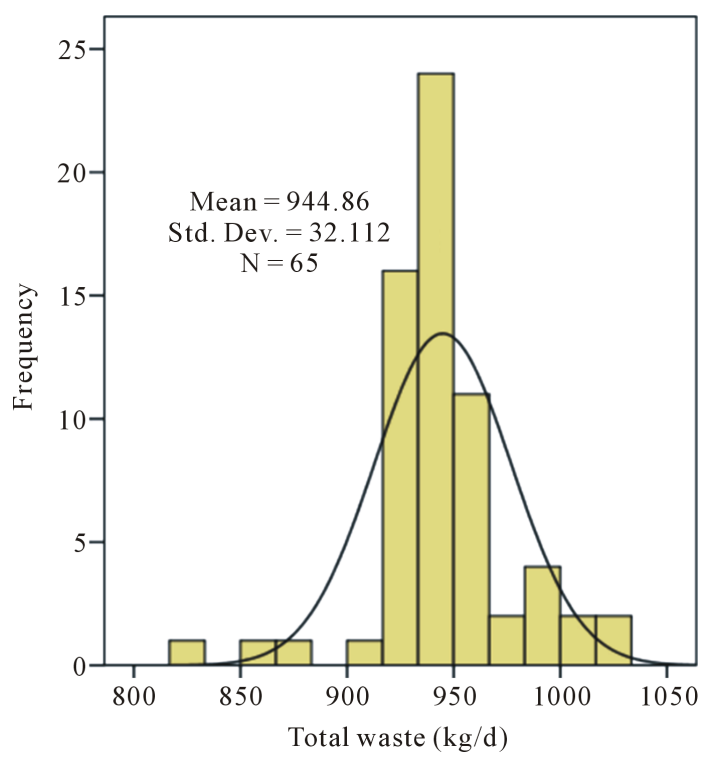

Figure 3. PDF of the total waste incinerated per day.

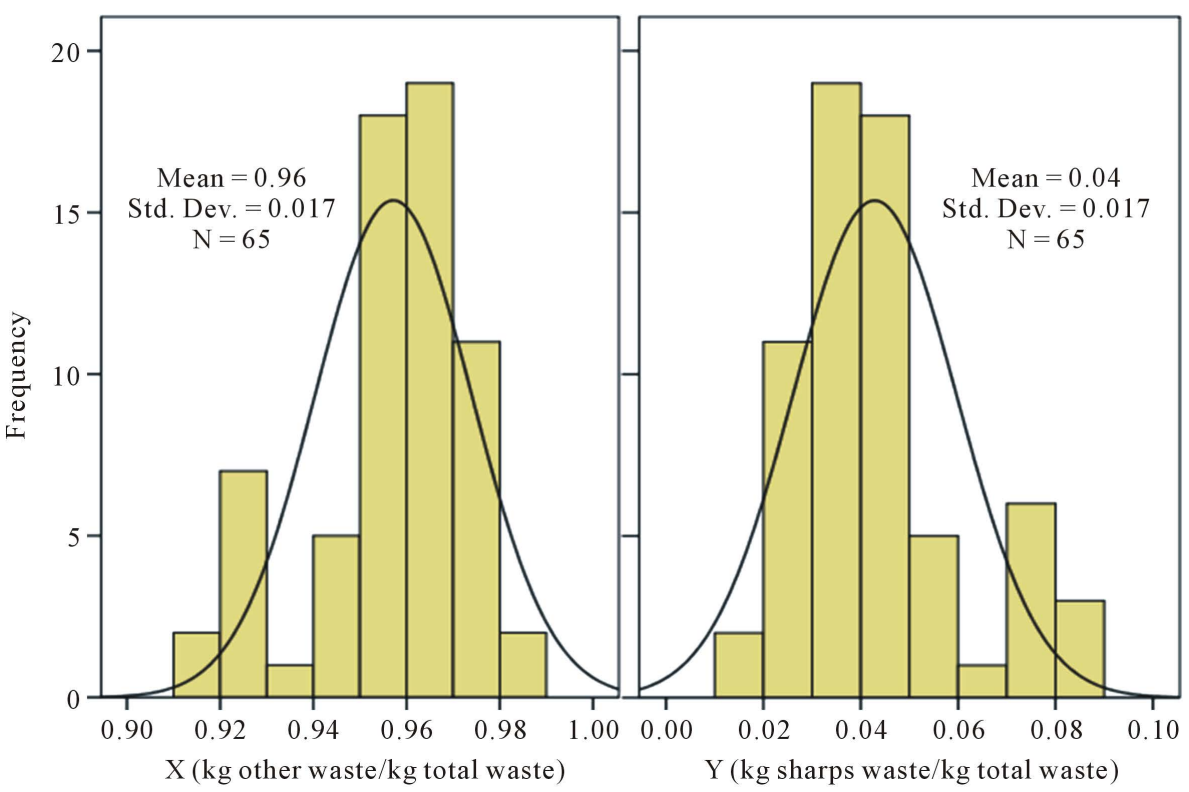

Figure 4. Histograms for the sharps waste and other waste composition data.

Table 3. Comparison of statistics for waste composition proportions $\mathrm{X}$ and $\mathrm{Y}$.

\begin{tabular}{ccc}
\hline & $\mathrm{X}(\mathrm{kg}$ other waste $/ \mathrm{kg}$ total $)$ & $\mathrm{Y}(\mathrm{kg}$ sharps $/ \mathrm{kg}$ total $)$ \\
\hline $\mathrm{N}$ & 65 & 65 \\
Mean & 0.9572 & 0.0428 \\
Std. Deviation & 0.01687 & 0.01687 \\
Skewness & -0.919 & 0.919 \\
Kurtosis & 0.189 & 0.189 \\
Minimum & 0.92 & 0.02 \\
Maximum & 0.98 & 0.08 \\
\end{tabular}




\subsection{Weight Reduction and Incinerator Ash Collection}

The total ash collected ranged between 20 and $87 \mathrm{~kg} /$ day with mean $51.2 \mathrm{~kg}$. Based on the standard deviation values of time series stronger fluctuations were noted on other waste than sharps waste, with values of 23.9 and 18.4 respectively. Figure 5 shows the probability density function for percent weight reduction data, also collected for 65 days consecutively. The average percent reduction in weight was observed to be $94.6 \%$ which is on the higher side since some of the incinerators range from $85 \%$ to $97 \%$. The observed average waste reduction is higher than the values reported for a district hospital incinerator [26]. The percent weight reduction is a measure of the extent to which the weight of the waste is decreased due to incineration. Such a higher value signifies that the incinerator is effective, leading to $51.2 \mathrm{~kg}$ of ashes for each $945 \mathrm{~kg}$ of waste incinerated (or $54.2 \mathrm{~kg}$ ash/ton). This reduce handling costs, and transportation costs for the toxic ashes.

Figure 5 presents the PDF of incinerator ash waste with mean value of 51.2 and standard deviation of 14.2, the value ranges between $20-90 \mathrm{~kg} /$ day. The total ash collected ranged between 20 and $87 \mathrm{~kg} /$ day with mean $51.2 \mathrm{~kg} /$ day. Based on the standard deviation values of time series stronger fluctuations were noted on other waste than sharps waste, with values of 23.9 and 17.4, respectively, as indicated in Table 2.

The final ash and other remaining materials are normally left to cool overnight and removed daily. As mentioned early, the incinerator was not function properly, as results sharps were not being destroyed completely making ash waste hazardous and still posing health and safety risk to the waste handlers. Also other waste such as pharmaceutical bottles, flammable bottles remained as ash waste due to improper segregation at the waste generation points.

\subsection{Analysis of Normalized Incineration Data}

The waste incineration data was normalized in order to compare the fluctuations in the time series using PDF, skewness and kurtosis. Normalized values, $X_{n}$, ranged between 0 and 1 , as reported in literature [15]. Table 4 summarizes the statistics for normalized data for other waste, sharps waste, total waste, sharps waste proportion and ash collected. Table 4 shows that in all cases, the median is below the mean, indicating that the data is skewed to the right. The ash collected data has a mean closer to $X_{n}=0.5$ while for the rest of the data the mean values are below the midpoint of the normalized scale.

Figure 6 shows the cumulative probability function for the normalized daily incineration data. A good similarity is observed for all data, with exception of ash collected, whereby, the curve is rather shifted to the right, with the lowest Skewness, indicating a tendency to approach normal distribution compared to the other data.

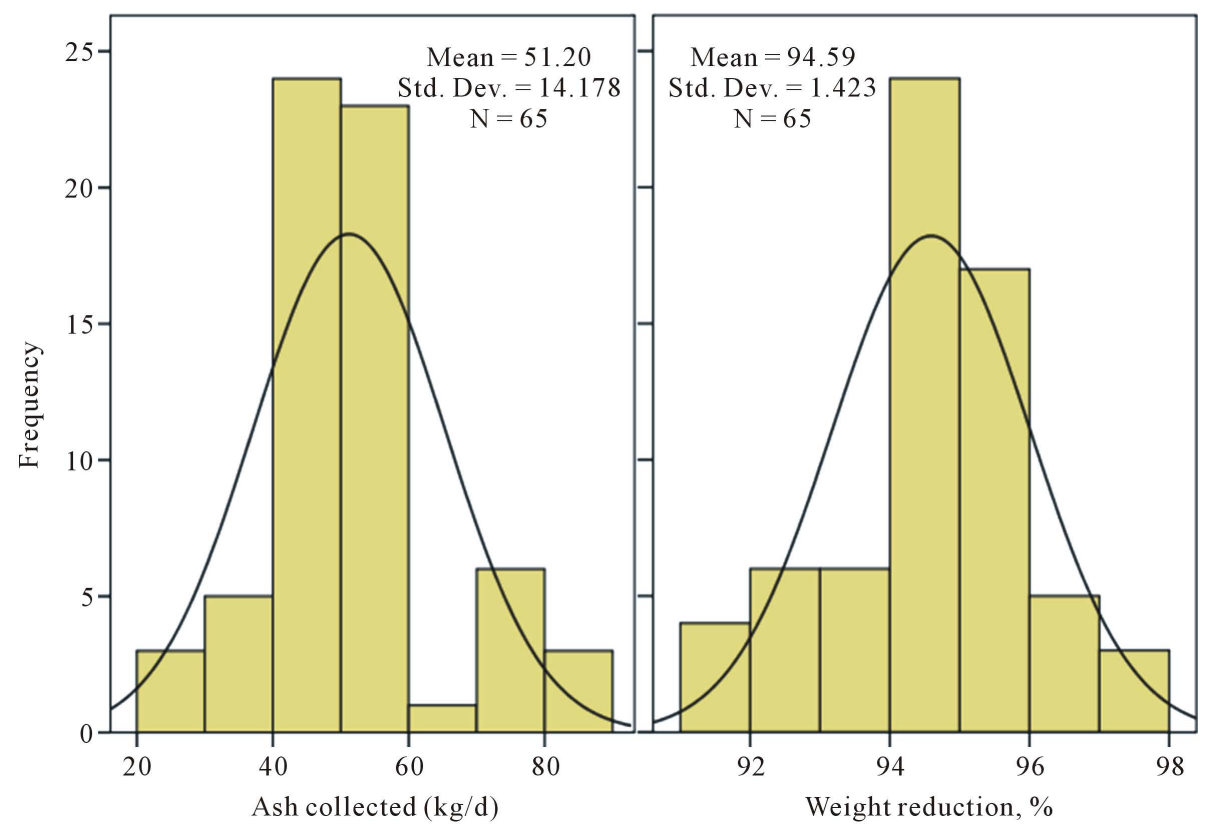

Figure 5. PDF of percent weight reduction data. 
Table 4. Statistics of normalized data.

\begin{tabular}{cccccc}
\hline & Other waste & Sharps waste & Total waste & Y (\% sharps) & Ash \\
\hline $\mathrm{N}$ & 65 & 65 & 65 & 65 & 65 \\
Mean, $\overline{\mathrm{X}}_{\mathrm{n}}$ & 0.422 & 0.363 & 0.353 & 0.385 & 0.466 \\
Median & 0.341 & 0.324 & 0.302 & 0.349 & 0.448 \\
Std. Deviation, $\sigma_{\mathrm{n}}$ & 0.247 & 0.240 & 0.232 & 0.243 & 0.212 \\
Skewness, $\mathrm{Sk}_{\mathrm{n}}$ & 0.970 & 1.034 & 1.231 & 0.903 & 0.609 \\
Kurtosis, $\mathrm{Ku}_{\mathrm{n}}$ & -0.052 & 0.570 & 1.074 & 0.268 & 0.724 \\
\hline
\end{tabular}

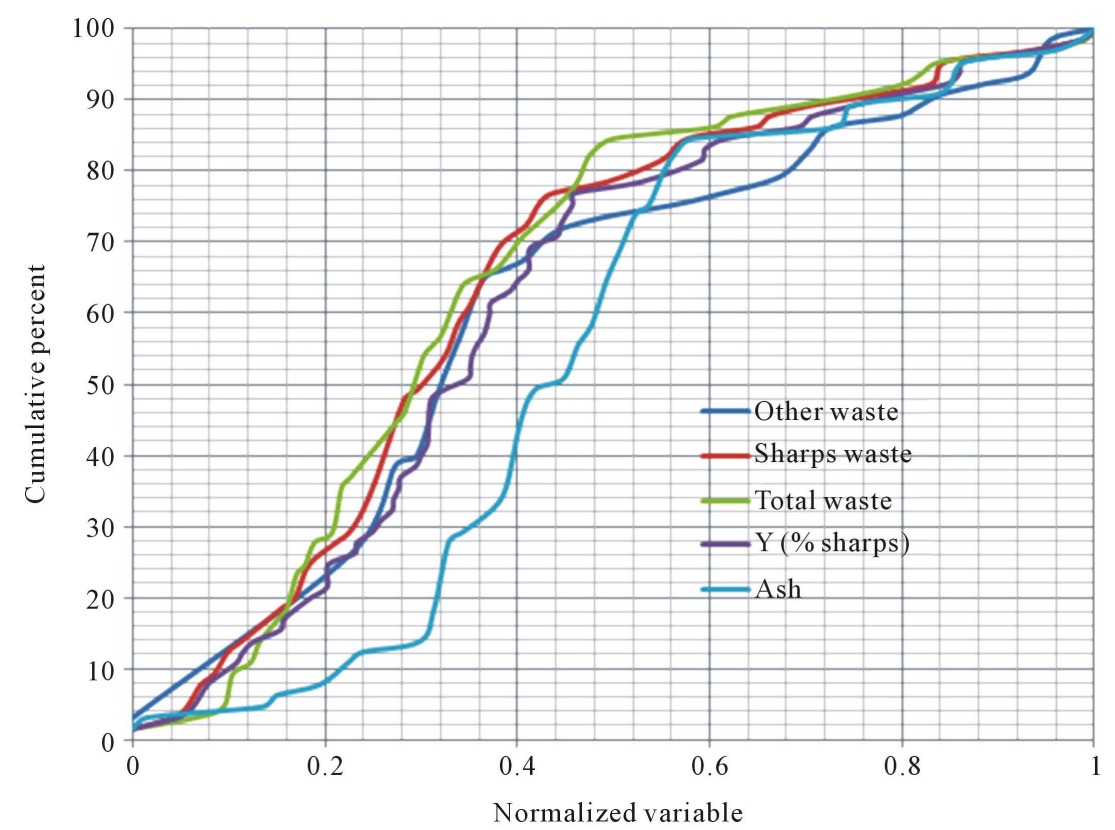

Figure 6. Cumulative probability function for the normalized daily incineration data.

The sharps waste, other waste and total waste data show that increasing values are associated with decreasing frequencies, which signifies data skewed to the right (positive Skewness) as indicated also in Table 4. However, the ash collected data shows a bi-modal characteristics but still with a tendency for the normalized mean value towards $X_{n}=0.5$. Figure 7 shows the PDFs of the normalized daily incineration data.

Based on Figure 7, the normalized sharps waste data shows the highest frequency at $X_{n}=0.3$, while for the other waste and total waste data the highest is at $X_{n}=0.25$. On the contrary, the ash collection data shows the bimodal trend with peaks at $X_{n}=0.3$ and 0.5 , respectively.

Thus, the normalized data shows clearly that the four data are from distinct systems governed by different factors. For example, sharps waste data is governed by number of emergency cases in the referral hospital, extent of segregation, health workers perceptions on sharps waste, availability of sharps waste containers and availability of injection devices. On the other hand, the factors affecting the ash collection data from the incinerator are further determined by incinerator performance (maximum temperatures reached, amount of waste loaded, incineration cycle time based on time interval between waste loading, burner efficiency, etc.), which are slightly linked to those affecting sharps waste, other waste and total waste loaded.

\subsection{Diesel Oil Consumption during Medical Waste Incineration}

The diesel oil consumption was observed to vary slightly between 355 and 370 L/day (or 45 and 46 L/cycle) with the average fuel oil consumption rate of 362 L/day as shown on Figure 8. 

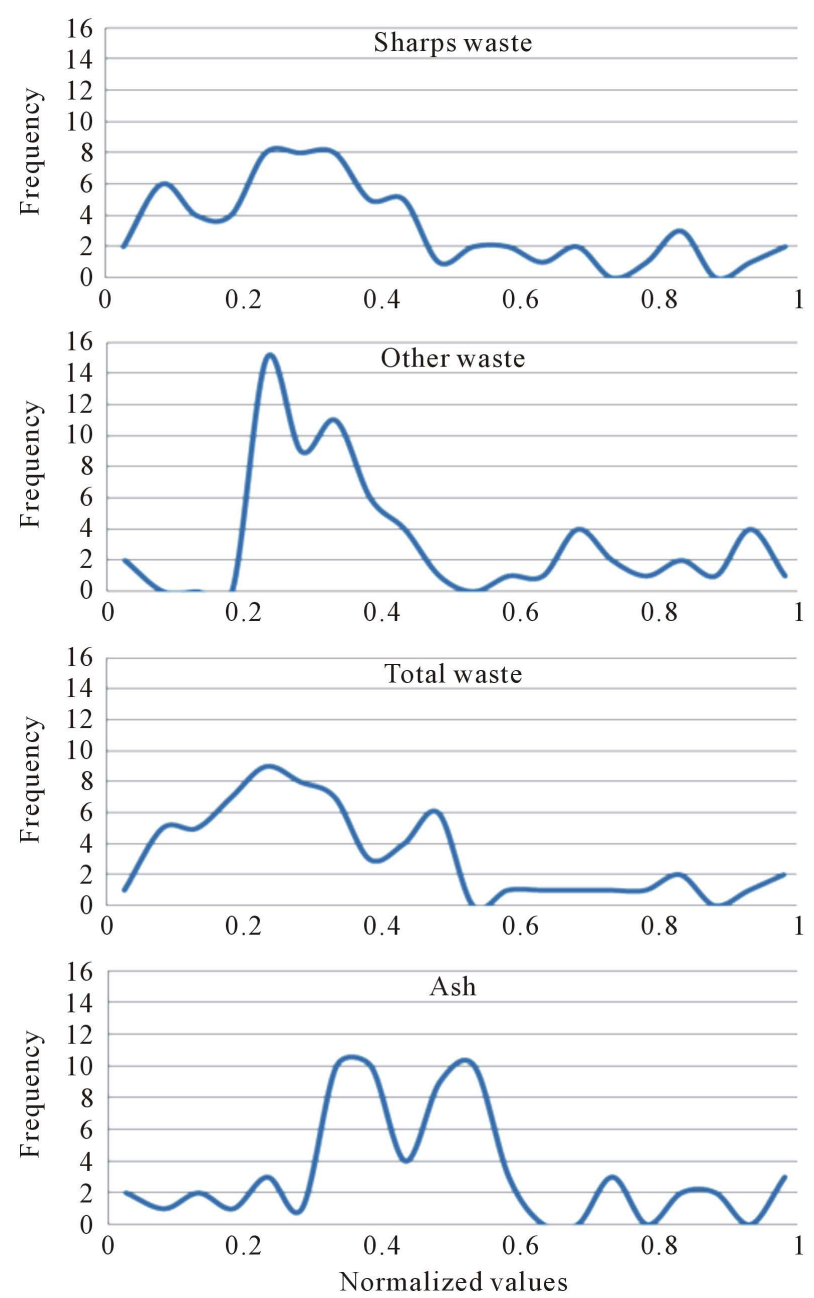

Figure 7. Probability density functions of the normalized daily incineration data.

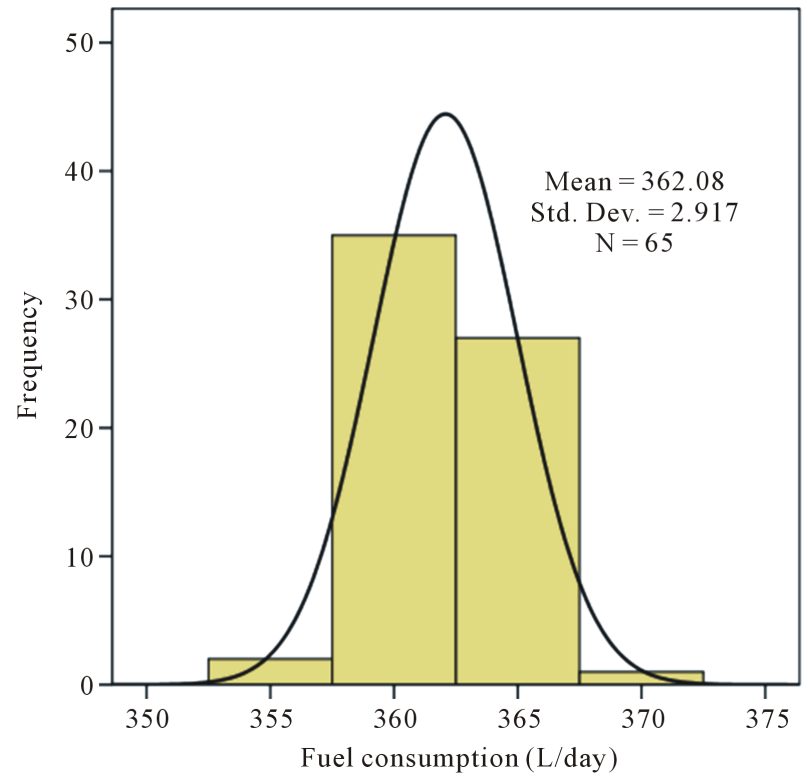

Figure 8. Probability density functions of daily diesel oil consumption. 
Detailed analysis of the fuel consumption data indicated that there were mainly four dominant fuel consumption rates, that is: 350, 355, 360 and 370 L/day, as shown in the pie chart (Figure 9). During the study one of the primary burners was defective although the same fuel consumption was observed. Thus, the incinerator performance was poor due to continuous diesel oil flow into burners causing fuel consumption rate to be high. Data for diesel oil reveals that the most of cycles were conducted at 360 L/day (54\%) followed by 365 litres/day (42\%) consumption and 355 Litres/day (3\%) and 370 L/day (1\%).Similar analysis was reported for a district hospital incinerator [12]. As indicated on probability density function, Figure 6, the $370 \mathrm{~L} /$ day (which is the highest) was issued during incinerator maintenance and repairs.

The higher values of diesel oil consumption rate were due to incinerator design, defective burners and leaking of diesel oil on filters and pipes thus increases running costs. This study took place during rainy season thus more wet waste contributed to poor incinerator performance. Moreover, proper maintenance schedule for incinerator was not followed for the following reasons: lack of spare parts for technicians to conduct planned preventive maintenance and lack of funds.

\subsection{Analysis of Fuel Effectiveness during Incineration}

Total waste incinerated per day was studied in relation with fuel consumption. Based on data from Figure 3 and Figure 8, the incinerator destroys about 1 ton of waste per day, consuming about 362 lts of diesel oil. This is equivalent to $945 \mathrm{~kg} / 362 \mathrm{~L} \cong 2.61 \mathrm{~kg} / \mathrm{L}$. This is a low fuel effectiveness when compared with a double chamber small scale incinerator for which the fuel effectiveness ranged between 2 and $5 \mathrm{~kg} / \mathrm{L}$ [11].

The fuel effectiveness was established as a ratio of $\mathrm{kg}$ waste incinerated to the liters of fuel used $(\mathrm{kg} / \mathrm{L})$. The mean value of fuel effectiveness was $2.62 \mathrm{~kg}$ waste per litre of diesel, which is too low. The values ranged between 2.35 and $2.85 \mathrm{~kg} / \mathrm{L}$. The distribution is closer to normal distribution with skewness of 0.182 as indicated in Figure 10. The lower values of fuel effectiveness can be due to loading wet waste (data collected during rainy season) which leads to high diesel oil consumption. The results showed that about $800-1020 \mathrm{~kg}$ of waste was incinerated per day, consuming 40 - 46 Litres of fuel per cycle. However, as the amount of incinerated waste increases, the fuel effectiveness increases as well. Two different linear relationships were observed between total waste incinerated and fuel effectiveness, depending on the average fuel consumption as shown in Figure 10.

The fuel effectiveness data was represented by a linear equation depending on the fuel consumption rate. The fuel consumption rate of $360 \mathrm{~L} /$ day led to a linear equation $\mathrm{Y}=0.0029 \mathrm{x}-0.0784$ with $\mathrm{R}^{2}=0.974$, while the fuel consumption rate of $365 \mathrm{~L} /$ day was represented by an equation $\mathrm{Y}=0.0026+0.1661$ with $\mathrm{R}^{2}=0.9812$. The highest fuel effectiveness occurs when total waste incinerated was highest, or when the fuel consumption is low. The fuel consumption could also be minimized by reducing the incineration cycle time. Thus, for good economics in operating the incinerator, means of reducing fuel consumption should be established.

\subsection{Incinerator Capacity}

The total waste incinerated per hour, defined as the incinerator capacity was also studied to assess the incinerator performance [12]. In order to establish the time series for incinerator capacity, the daily data was divided by the cycle time of 8 hours, giving $\mathrm{kg} / \mathrm{h}$. Figure 11 presents the PDF of incinerator capacity data in $\mathrm{kg} / \mathrm{hour}$ with

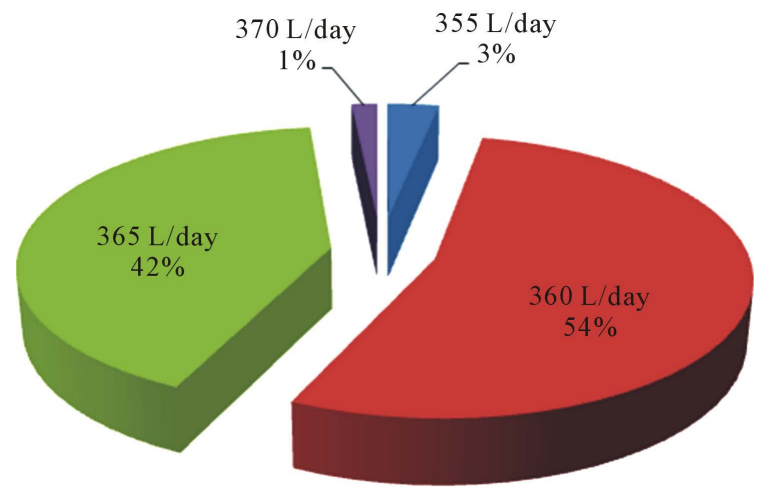

Figure 9. Distribution of daily fuel consumption rate data. 


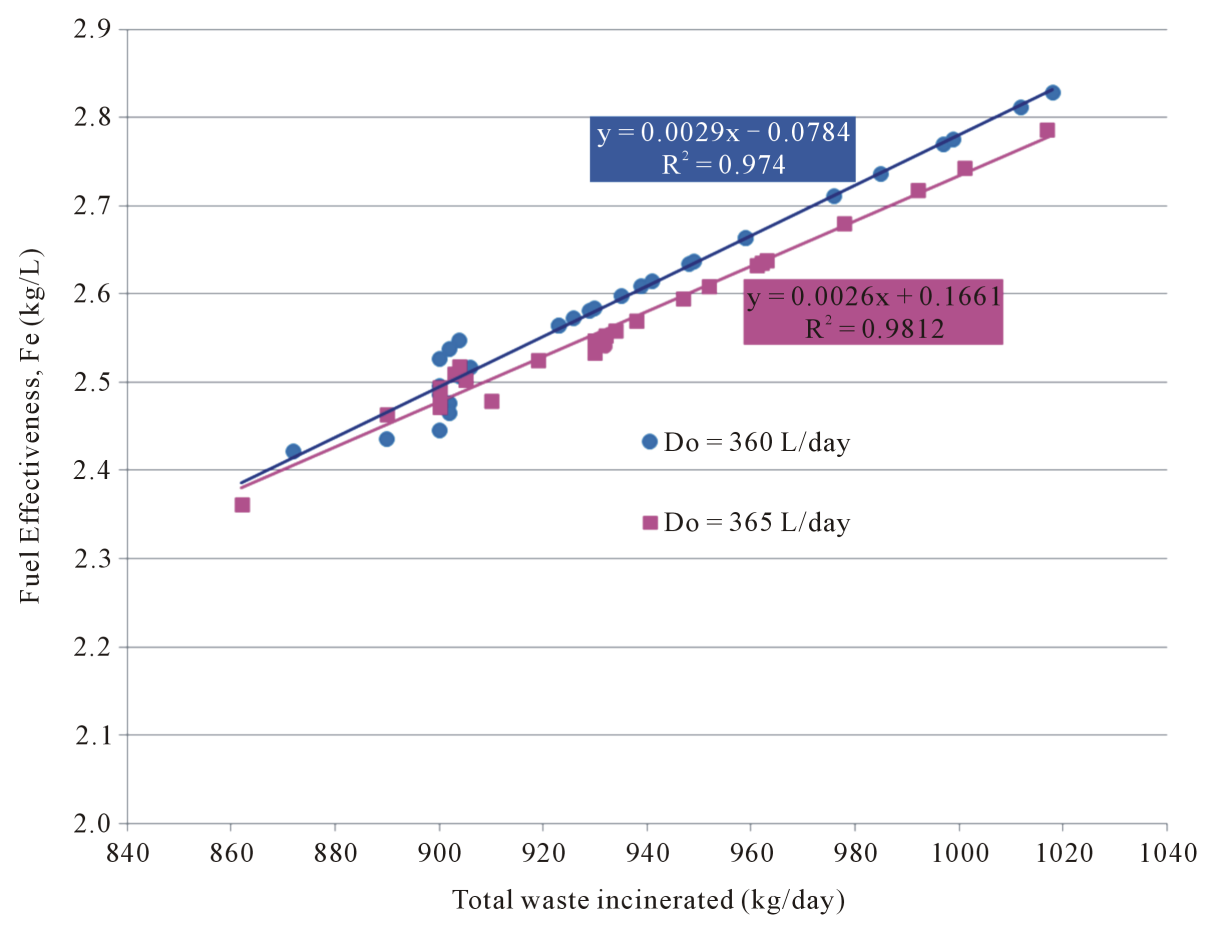

Figure 10. Variation of fuel effectiveness with total waste incinerated.

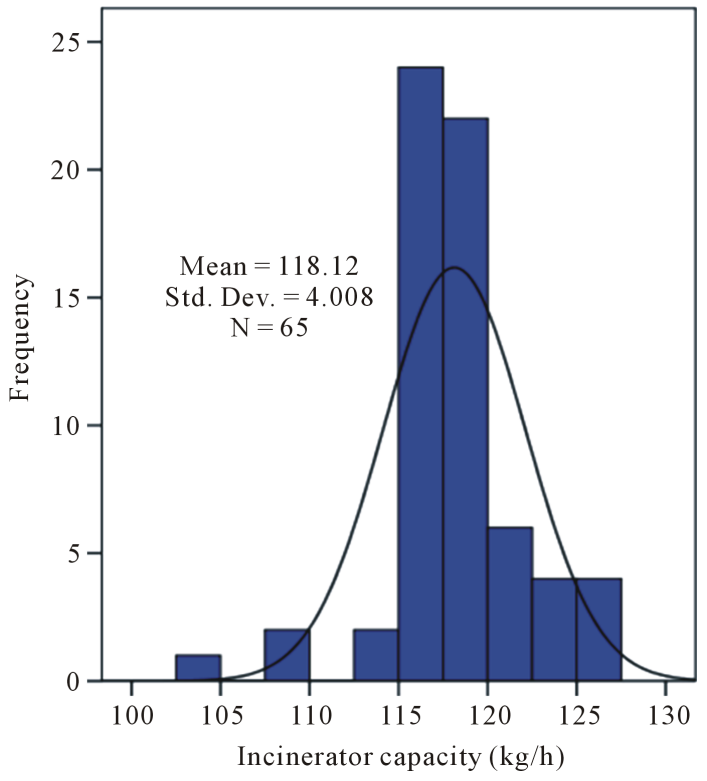

Figure 11. Probability density function for incinerator capacity data.

mean value of $118.2 \mathrm{~kg} / \mathrm{h}$. The values of incinerator capacity ranged between 100 and $140 \mathrm{~kg} / \mathrm{h}$. The values are higher compared to the reported data for a district hospital incinerator which ranged between 20 and $50 \mathrm{~kg} / \mathrm{h}$ [12]. However, new incinerator designs with air pollution control device with the similar capacity (83 - 122 $\mathrm{kg} / \mathrm{cyle}$ ) are available in Tanzania, with minimum fuel oil consumption of $20 \mathrm{~L} / \mathrm{h}$ [26]. The major difference between the new incinerator design and the large scale incinerator at MNH is the operating time. While the former operates for one cycle per day (about 40 minutes) destroying up to $122 \mathrm{~kg}$ which is the total infectious waste generation rate, the latter incinerates up to $140 \mathrm{~kg} / \mathrm{h}$ for 8 hours. 


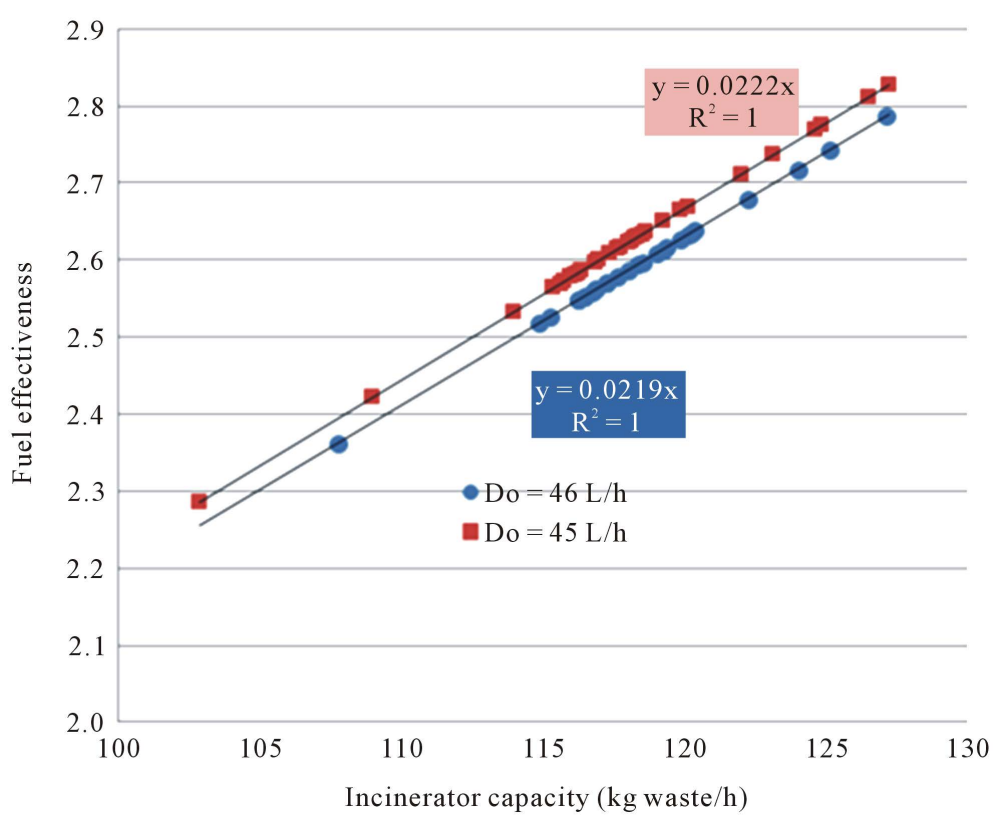

Figure 12. Variation of fuel effectiveness with incinerator capacity.

When plotted against the incinerator capacity, the fuel effectiveness increased linearly with the former (Figure 12). Two linear curves were still observed, with linear equations giving $\mathrm{Y}=0.0222 \mathrm{x}$ and $\mathrm{Y}=0.0219 \mathrm{x}$, with $\mathrm{R}^{2}=1$ for both cases when the fuel consumption was recorded as $46 \mathrm{~L} / \mathrm{h}$ and $45 \mathrm{~L} / \mathrm{h}$ respectively, with lower fuel consumption rate giving higher fuel effectiveness similar to results in Figure 8.

\section{Conclusion}

Based on the study, it can be concluded that the incinerator performance was excellent in terms of percent weight reduction, that is, $94.6 \%$ compared to reported values in the literature. The quantity of waste treated was high about $945 \mathrm{~kg}$ /day justifying for the large scale unit.The incinerator capacity data reported in this study was high compared to small scale incinerator, with chance of improvement through reduction of cycle time and also by proper segregation and storage. Medium scale incinerators with higher capacity and minimal fuel consumption are available in the Tanzanian market. The fuel effectiveness was however on the lower side, due to high rate of fuel consumption compared to the amount of waste incinerated. The values ranged between 2.35 and 2.85 with average of $2.62 \mathrm{~kg} / \mathrm{L}$. Moreover, the fuel effectiveness increased linearly with total waste incinerated and also with incinerator capacity. On the other hand, the amount of sharps waste loaded into the incinerator was rather too small compared to data reported in the literature (up to $25 \%$ ). However, the fuel consumption was too high compared to small scale incinerators of similar capacity, observation which requires prompt action by the MNH management. The amount of ash collected was small leading to minimized cost of transportation to the final disposal sites.

\section{Acknowledgements}

The completion of this study has been the result of assistance received from various staff. Gratitude goes to MNH Management team (for permission to use Muhimbili National Hospital as study area) and all staff in the Engineering department for their assistance during data collection.

\section{References}

[1] MNH-WMPG, Waste Management Procedure and Guideline, Muhimbili National Hospital (MNH), 2004.

[2] Gidarakos, E., Petrantonaki, M., Anastasiadou, K. and Schramm, W. (2009) Characterization and Hazard Evaluation of Bottom Ash Produced from Incinerated Hospital Waste. Journal of Hazardous Materials, 172, 935-942. http://dx.doi.org/10.1016/j.jhazmat.2009.07.080 
[3] Manyele, S.V. (2004) Effects of Improper Hospital Waste Management or Occupational Health and Safety. African Newsletter on Occupational Health and Safety, 14, 30-33.

[4] Wang, Q. (2004) Aspects of Pretreated Hospital Waste Biodeg-Radation in Landfills. Proceedings of 7th International Landfill Symposium, Cagliari, 59-66.

[5] Wanasolo, W., Manyele, S.V. and Makunza, J. (2013) A Kinetic Study of Anaerobic Biodegradation of Food and Fruit Residues during Biogas Generation Using Initial Rate Method. Engineering, 5, 577-586. http://dx.doi.org/10.4236/eng.2013.57070

[6] Mesfin, K.D., Kassahun, A.G., Andamlak, G.A. and Zemedu, M.T. (2013) Assessment of the Health Care Waste Generation Rates and Its Management System in Hospitals of Addis Ababa, Ethiopia. BioMedical Central Public Health, 13, 1-9.

[7] Manyele, S.V. and Mujuni, C.M. (2010) Current Status of Sharps Waste Management in Lower Level Health Facilities in Tanzania. Tanzania Health Research Journal, 12, 257-264. http://dx.doi.org/10.4314/thrb.v12i4.53362

[8] Powell, F. (1987) Air Pollutant Emissions from the Incineration of Hospital Wastes: The Alberta Experience. Journal of the Air Pollution Control Association, 37, 836-839. http://dx.doi.org/10.1080/08940630.1987.10466278

[9] Singh, S. and Prakash, V. (2007) Toxic Environmental Releases from Medical Waste Incineration. Environmental Monitoring, 132, 67-81. http://dx.doi.org/10.1007/s10661-006-9503-3

[10] Santoleri, J.J. (2009) Design and Operating Problems of Hazardous Waste Incinerators. Environmental Progress, 4, 246-251. http://dx.doi.org/10.1002/ep.670040408

[11] Walter, R. (2002) Combustion and Incineration Processes. 3rd Edition, Marcel Dekker, New York.

[12] Manyele, S.V. and Kagonji, I.S. (2012) Analysis of Medical Waste Incinerator Performance Based on Fuel Consumption and Incineration Cycle Times. Engineering, 4, 625-635. http://dx.doi.org/10.4236/eng.2012.410080

[13] Sharifah, S.A.K., Abidin, H.Z., Sulaiman, M.R., Khoo, K.H. and Ali, H. (2008) Combustion Characteristics of Malaysian Municipal Solid Waste and Predictions of Air Flow in Rotary Kiln Incinerator. Journal of Material Cycles and Waste Management, 10, 116-123. http://dx.doi.org/10.1007/s10163-008-0207-3

[14] Min, B.-Y., Lee, Y., Yun, G.-S., Lee, K.-W. and Moon, J.-K. (2015) Volume Reduction of Radioactive Combustible Waste with Oxygen Enriched Incinerator. Annals of Nuclear Energy, 80, 47-51. http://dx.doi.org/10.1016/j.anucene.2015.01.023

[15] Manyele, S.V. and Kagonji, I.S. (2012) Assessment of Incineration Process Performance in District Hospital Using Statistical Analysis. Engineering, 4, 421-434. http://dx.doi.org/10.4236/eng.2012.48056

[16] Hamoda, H.M., Tomi, H.N. and Bahman, Q.Y. (2005) Variations in Hospital Waste Quantities and Generation Rates. Journal of Environmental Science and Health, 40, 467-476. http://dx.doi.org/10.1081/ESE-200045650

[17] Engdaw, D., Sulaiman, H. and Leta, S. (2009) Determining the Generation Rate and Composition of Solid Health Care Waste at Gondar University Hospital. Ethiopian Journal of Health and Biomedical Sciences, 1, 17-21.

[18] Longe, E.O. and Williams, A. (2006) A Preliminary Study of Medical Waste Management in Lagos Metropolis, Nigeria. Iranian Journal of Environmental Health Science \& Engineering, 3, 133-139.

[19] Manyele, S.V. and Anicetus, H. (2006) Management of Medical Waste in Tanzanian Hospitals. Tanzania Health Research Bulletin, 8, 177-182.

[20] Sawalem, M., Selic, E. and Herbell, J.D. (2009) Hospital Waste Management in Libya: A Case Study. Waste Management, 29, 1370-1375. http://dx.doi.org/10.1016/j.wasman.2008.08.028

[21] Nemathaga, F., Maringa, S. and Chimuka, L. (2008) Hospital Solid Waste Management Practices in Limpopo Province, South Africa: A Case Study of two Hospitals. Waste Management, 28, 1236-1245. http://dx.doi.org/10.1016/j.wasman.2007.03.033

[22] Idowu, I., Alo, B., Atherton, W. and Al Khaddar, R. (2013) Profile of Medical Waste Management in Two Healthcare Facilities in Lagos, Nigeria: A Case Study. Waste Management and Research, 31, 494-501. http://dx.doi.org/10.1177/0734242X13479429

[23] Manyele, S.V. and Lyasenga, T.J. (2010) Factors Affecting Medical Waste Management in Low-Level Health Facilities in Tanzania. African Journal of Environmental Science and Technology, 4, 304-318.

[24] Kagonji, I.S. and Manyele, S.V. (2010) Analysis of the Measured Medical Waste Generation at Amana and Ligula Hospitals Using Statistical Methods. African Journal of Environmental Science and Technology (AJEST), 5, 815-833.

[25] MoHSW (2006) National Infection Prevention and Control Guidelines for Healthcare Services in Tanzania. Dar-es Salaam.

[26] Kagonji, I.S., Manyele, S.V. and Mrisho, J. (2011) Assessment of a Double Chamber Incinerator Performance Based on Ash Characteristics. Engineering, 3, 1045-1053. http://dx.doi.org/10.4236/eng.2011.310130 
[27] Zhao, L.J., Zhang, F.-S., Chen, M.J., Liu, Z.G. and Wu, J.Z. (2010) Typical Pollutants in Bottom Ashes from a Typical Medical Waste Incinerator. Journal of Hazardous Materials, 173, 181-185. http://dx.doi.org/10.1016/j.jhazmat.2009.08.066

[28] Patwary, M.A., O’Hare, W.T., Street, G., Maudood Elahi, K., Hossain, S.S. and Sarker, M.H. (2009) Quantitative Assessment of Medical Waste Generation in the Capital City of Bangladesh. Waste Management and Research, 29, $2392-$ 2397. http://dx.doi.org/10.1016/j.wasman.2009.03.021 